\title{
Predicted No-Effect Concentration of Roundup in the Composition with Pharmaceutical Chlorpromazine or Heating Causes Similar Biochemical Disturbances in Bivalve Mollusk Unio Tumidus
}

\section{Vira Khoma}

Ternopil's'kyi natsional'nyi pedahohichnyi universytet imeni Volodymyra Hnatiuka

Viktoria Martinyuk

Ternopil's'kyi natsional'nyi pedahohichnyi universytet imeni Volodymyra Hnatiuka

\section{Tetyana Matskiv}

I Horbachevsky Ternopil National Medical University: Ternopil's'kij nacional'nij medicnij universitet imeni I A Gorbacevs'kogo

\section{Lesya Gnatyshyna}

I Horbachevsky Ternopil National Medical University: Ternopil's'kij nacional'nij medicnij universitet imeni

I A Gorbacevs'kogo

\section{Vitaliy Baranovsky}

Ternopil's'kyi natsional'nyi pedahohichnyi universytet imeni Volodymyra Hnatiuka

Mykola Gladiuk

Ternopil's'kyi natsional'nyi pedahohichnyi universytet imeni Volodymyra Hnatiuka

\section{Brigita Gylytè}

Nature Research Centre

\section{Levonas Manusadžianas}

Nature Research Centre

Oksana Stoliar ( $\triangle$ Oksana.Stolyar@gmail.com )

Ternopil's'kyi natsional'nyi pedahohichnyi universytet imeni Volodymyra Hnatiuka https://orcid.org/0000-0002-8579-2881

\section{Research Article}

Keywords: Bivalve mollusc, Roundup, Heating, Chlorpromazine, Antioxidants, Zinc.

Posted Date: July 12th, 2021

DOl: https://doi.org/10.21203/rs.3.rs-632574/v1 
License: (c) (i) This work is licensed under a Creative Commons Attribution 4.0 International License. Read Full License 


\section{Abstract}

The ability of bioindicators to reflect the specific impacts in complex exposures is unpredicted. This study aimed to track the particular effects of pesticide Roundup $(\mathrm{Rn})$ and antipsychotic drug chlorpromazine $(\mathrm{Cpz})$ on the mussel Unio tumidus at environmentally relevant mixtures. The mussels were treated by $\mathrm{Rn}$ $\left(17 \mu \mathrm{g} \mathrm{L}^{-1}\right), \mathrm{Cpz}\left(18 \mu \mathrm{g} \mathrm{L}^{-1}\right)$, mixture of $\mathrm{Rn}$ and $\mathrm{Cpz}$ at $18{ }^{\circ} \mathrm{C}(\mathrm{RnCpz})$ as well as by $\mathrm{Rn}$ at $25^{\circ} \mathrm{C}(\mathrm{RnT})$. Digestive glands were examined after 14 days of exposure. The indexes of stress response (total antioxidant capacity, glutathione (GSH\&GSSG), metallothioneins (MTSH and Zn-MT), protein carbonyls levels), and markers of metabolic and detoxication (CYP450 related (EROD), Glutathione $S$ transpherase (GST), cholinesterase, caspase-3, citrate synthase (CS) activities), lysosomal membrane integrity, and Zn level were analyzed. Mostly common responses of mussels were indicated as the increase of oxidative stress, MTSH (except Cpz-group), EROD and CS (except Rn-group) responses. Rn-group indicated almost no-effect or abnormal for expected symptoms effect. However, under the heating Rn caused the decrease of $\mathrm{Zn}$ accumulation and loss of lysosomal integrity. Cpz provoked major response diverseness: a decrease in Zn and GST levels and an increase in lysosomal integrity. Thus, complex exposures abolished the individual response traits. Summarising, the application of integrated indices has benefits when evaluating the effects of complex exposures.

\section{Highlights}

1. Exposure of bivalves to Roundup (Rn) and heating $(T)$ or chlorpromazine (Cpz) in nanomolar concentrations.

2. Antioxidants and metallothioneins represent common hormetic-like responses.

3. Specific responses to $\mathrm{Rn}$ and $\mathrm{Cpz}$ were abolished in their joint exposure.

4. RnT decreases tissue $\mathrm{Zn}$ and lysosome integrity indicating damage.

\section{Introduction}

Bivalve molluscs are recognised bioindicators of surface water chemical pollution and climate changes. Various integrative biomarkers have been utilised for characterising the health status of these organisms affected by abiotic stresses (Louis et al. 2020). However, specific responses of molluscs to certain xenobiotics are not well understood and were examined generally in the exposures to single substances at high concentrations (Giménez and Nunes 2019), which are hardly expected in the environment unless the accidental release of pollutants occurs. The demand for "evidence-based ecotoxicology" (Martin et al. 2019) includes elaborating of the environmentally realistic models for the risk assessment, including the testing of the responses to combine exposures at low environmental concentrations. This study aimed to track the particular effects of pesticide Roundup (Rn) and antipsychotic drug chlorpromazine (Cpz) on the mussel Unio tumidus at environmentally relevant mixtures. 
The substances selected for the study, herbicide Roundup (Rn) and drug chlorpromazine (Cpz), are common aquatic pollutants. The Rn (a commercial form of glyphosate) belongs to the most frequently used pesticides globally as a weed killer (Matozzo et al. 2020). The levels of glyphosate in the freshwaters reach hundreds of $\mu \mathrm{g} \mathrm{L}^{-1}$ (Bonansea et al. 2018). It has been suggested that one of the possible reasons for glyphosate toxicity could be its chelating properties towards divalent metal ions that alter the bioavailability of nutrients in plants and soil microorganisms (Mertens et al. 2018). Therefore, its impact on the metal metabolism in the non-targeted species can be expected. However, the signs of its toxicity for aquatic species are mostly reported as the oxidative stress responses, endocrine, immune and histological alterations at as low as $0.1-100 \mu \mathrm{g} \mathrm{L}^{-1}$ concentrations in the in vitro, ex vivo, acute and subchronic in vivo exposures (El Haj et al. 2019; Khoma et al. 2020, 2021; Matozzo et al. 2020 and references therein).

Another studied chemical $\mathrm{Cpz}$ is the first generation neuroleptic medication known as dopamine $\mathrm{D}_{2}$ receptor antagonist (Li et al. 2016). The Cpz investigation was motivated by its popularity. Among 197 substances analysed in hospital wastewater, chlorpromazine belongs to 15 particularly hazardous chemicals present at high concentrations $\left(\mathrm{mg} \mathrm{L}^{-1}\right)$ (Frédéric and Yves 2014). The persistence of $\mathrm{Cpz}$ in river water and strong adsorption on sediments have also been reported (Jiménez et al. 2016). According to Baresel et al. (2015), the mean Cpz concentration in Swedish sewage treatment plant effluents amounts to $11.3 \mathrm{ng} \mathrm{L}^{-1}$. Recently, chlorpromazine has been found to have antiviral activity in vitro against the influenza virus, HIV. Actually, it is listed among "the most promising molecules for inhibiting coronaviruses in human cells" (Stip et al. 2020). The drug is known to interact with the cell membrane dynamin and block clathrin-dependent endocytosis essential for coronavirus entry into the host cell (Plaze et al. 2020). Consequently, its input into the water runoff is expected to be enhanced. The biological effects of $\mathrm{Cpz}$ are associated with calcium homeostasis (Xu et al. 2010) and manganese toxicity (Nelson et al. 2018). Therefore, its biochemical effects expected to be related to the involvement in metals uptake and metabolism. High toxic pressure of $\mathrm{Cpz}$ has been confirmed on the fish plasma model in the concentration of $36 \mathrm{ng} \mathrm{L}^{-1}$ (Miller et al. 2019). However, the results of acute and chronic exposures of cladoceran Daphnia magna (Oliveira et al. 2015; Alkimin et al. 2020) and mussels Mytilus galloprovincialis (Yang et al. 2011) to $\mathrm{Cpz}$ in a range from 0.01 to $250 \mu \mathrm{g} \mathrm{L}^{-1}$ almost did not show the changes in terms of physiological and biochemical parameters.

The elevated temperature has been shown to exacerbate the toxicity or distort effects in bivalve molluscs induced by xenobiotics including mixtures containing Roundup (Negri et al. 2013; Patra et al. 2015; Payton et al. 2016; Louis et al. 2020; Khoma et al. 2021). Mainly, metal metabolism and toxicity depend on thermal stress, and lysosomal biomarkers reflect this impact in mollusks (Izagirre et al. 2014).

Based on our own experience (Khoma et al. 2020, 2021) and aiming to provide environmentally expected limits of the impact, we used the low Rn concentration of $17 \mu \mathrm{g} \mathrm{L}^{-1}$ that corresponds to $6.1 \mu \mathrm{g} \mathrm{L}^{-1}$ or $36 \mathrm{nM}$ of glyphosate. This concentration commensurate with approximately 0.2 of Predicted No Effect Concentration (PNEC), the estimate derived from multispecies data for long-term exposures (Maycock et 
al. 2012). Cpz concentration of $18 \mu \mathrm{g} \mathrm{L}^{-1}$ or $57 \mathrm{nM}$ has been chosen to cause minor physiological effects in aquatic animals (Oliveira et al. 2015). The duration of exposure (14 days) and two temperatures $\left(18\right.$ and $25^{\circ} \mathrm{C}$ ) were based on the previous experience (Khoma et al. 2021), the latter in relevance to the range of water temperatures in the sampling area at the Dniester River basin.

Due to the suspected ability of both substances to affect metal metabolism, we focused on the metallothionein-related thiols and their participation in zinc accumulation, the level of glutathione (GSH/GSSG), and lysosomal integrity. Also, we evaluated the oxidative stress and biotransformation activities (cytochrome P450-related ethoxyresoruphine $O$-diesterase and glutathione $S$-transferase), metabolic activity (citrate synthase), neurotoxicity (basing on the cholinesterase activity), and apoptosis (through the activity of caspase-3, the central executive enzyme). An integrative analysis of the biomarker responses was applied for the comparison of experimental groups.

\section{Materials And Methods}

Methodology used is given in detail in Supplementary materials.

\subsection{Chemicals}

All reagents were of the Reagent grade or higher (S1 Appendix). They were obtained from Sigma-Aldrich (USA) or the Synbias (Ukraine). Roundup (Rn) formulation was Roundup MAX, Monsanto, USA, and chlorpromazine (Cpz) was of pharmaceutical grade, AMINAZINUM, Pat "Halychfarm", ATX N05A A01.

\subsection{Experimental groups}

Adult bivalve molluscs Unio tumidus Philipson, 1788 (Unionidae) ( 6 years old, $~ 8.5 \mathrm{~cm}$ length, and 60$70 \mathrm{~g}$ weight) were collected in a river site assumed to be a reference (Gnatyshyna et al. 2020). Specimens were transported to the laboratory and preacclimated to the laboratory conditions for up to seven days after the capture in the aerated, dechlorinated, softened tap water and fed $500 \mathrm{mg}$ of Tropical SuperVit Basic contained beta-1.3/1.6-glucan twice a week. After that, molluscs were distributed randomly to five groups. The first group was exposed to the aquarium water only and was considered control (C). The $\mathrm{Rn}$ - and RnT-groups were exposed to organophosphonate pesticide Roundup MAX (17 $\mu \mathrm{g}$ $\mathrm{L}^{-1}$, corresponding to $6.1 \mu \mathrm{g} \mathrm{L}-1$ or $36 \mathrm{nM}$ of glyphosate) at the temperatures $18^{\circ} \mathrm{C}$ and 25 ${ }^{\circ} \mathrm{C}$, respectively. The temperature was increased gradually in the RnT-group during $24 \mathrm{~h}$. The Cpz-group was exposed to $18.0 \mu \mathrm{g} \mathrm{L}^{-1}$ or $56 \mathrm{nM}$ of $\mathrm{Cpz}$, and the RnCpz-group - to a mixture of Rn and $\mathrm{Cpz}$ at $18{ }^{\circ} \mathrm{C}$. The duration of exposure was 14 days. Water was changed and chemicals replenished every two days. Throughout the experiment, molluscs were fed with the same regularity. No mortality was detected during the experimental exposures. 
After exposures, molluscs were dissected on ice. For lisosomal membrane stability and cholinesterase activity, the samples were utilised immediately. For all analyses except metallothioneins and caspase-3, tissues were homogenized (10\% w/v) in $0.1 \mathrm{M}$ phosphate buffer, $\mathrm{pH} 7.4$, containing $100 \mathrm{mM} \mathrm{KCl}$ and 1 mM EDTA, as well as $0.1 \mathrm{mM}$ phenylmethylsulfonyl fluoride (PMSF) for proteolysis inhibition. Homogenates were centrifuged at $6000 \mathrm{~g}$ for $10 \mathrm{~min}$, and the resulting supernatant was kept at $-40^{\circ} \mathrm{C}$. For the analysis of cholinesterase, the $10 \% \mathrm{w} / \mathrm{v}$ homogenate was prepared in the same buffer without PMSF. The protein concentration was analysed in the $6000 \mathrm{~g}$ supernatant according to the method of Lowry et al. (1951), using bovine serum albumin as the protein standard.

\subsection{Assays for metallothionein and glutathione}

Concentration of metallothioneins protein (MT) was assessed using 5,5'-dithio-bis(2-nitrobenzoic acid) (DTNB) reduction method after the ethanol/chloroform extraction from tissue 1:3 w/v homogenate in 20 $\mathrm{mM}$ Tris-sucrose buffer with $0.1 \%$ ß-mercaptoethanol, $0.5 \mathrm{mM}$ PMSF, $6 \mu \mathrm{M}$ leupeptine (Viarengo et al. 1997). The concentration of MT was expressed in $\mu \mathrm{g} \mathrm{g}^{-1}$ tissue FW.

For the evaluation of Zn concentration in metallothioneins (Zn-MT), $70 \mathrm{mg}$ of tissue per individual (to a total of $350 \mathrm{mg}$ from five specimens in the group) were combined. Two replices for each group were accomplished. The samples were homogenized in $10 \mathrm{mM}$ Tris- $\mathrm{HCl}$ buffer, $\mathrm{pH} 8.0$ containing $10 \mathrm{mM} \beta$ mercaptoethanol and $0.1 \mathrm{mM}$ PMSF and subjected to the isolation of thermostable supernatant. The MT-contained fractions were isolated from the supernatant by size-exclusion chromatography on Sephadex G-50 with necessary adjustments needed to avoid their oxidation (Roesijadi and Fowler 1991). Low weight (approximately $7 \mathrm{kDa}$ ) fractions with high absorbance at $254 \mathrm{~nm}$ and high $\mathrm{D}_{254} / \mathrm{D}_{280}$ density ratio were identified as putative MTs-containing peak and pooled (to the total of $10 \mathrm{~mL}$ ) for the $\mathrm{Zn}$ determination.

Total glutathione and oxidized glutathione (GSSG) concentrations were quantified by the glutathione reductase recycling assay (Griffith 1980) in the protein-free extract of homogenate using DTNB.

Concentration was expressed as nmol g-1 $\mathrm{FW}$. The concentration of the reduced glutathione (GSH) was calculated as the difference between the total glutathione and GSSG concentrations. The redox-index of glutathione (RI GSH) as the ratio of concentrations GSH/GSSG was calculated.

\subsection{Oxidative stress and toxicity assays}

Total antioxidant capacity (TAC) was determined as ABTS radical scavenging activity (Re et al. 1999). ABTS ${ }^{*+}$ radical cations (ABTS*) were generated from 2,2'-Azino-di-[3-ethylbenzthiazoline sulphonate] (ABTS) by potassium persulfate. The ascorbic acid was used as the reference compound. The reduction in absorbance of ABTS* solution was recorded at $734 \mathrm{~nm}$. The result was compared with control (only ABTS* solution).

Protein carbonyls (PC) were determined as an index of protein oxidation in the sediment of $10 \% \mathrm{w} / \mathrm{v}$ homogenate in sulfosalicylic acid after its centrifugation by reaction with 2,4-dinitrophenylhydrazine 
(DNPH) (Reznick and Packer 1994). The concentration of carbonyls was expressed in nmol PC per g FW.

Cholinesterase (ChE, EC 3.1.1.7) activity was determined in the homogenate according to the colorimetric method of Ellman et al. (1961) at $25^{\circ} \mathrm{C}$. Acetylcholine iodide (ATCh) was used with DTNB as the thiol indicator. Enzyme activity was referred to the protein content.

Lysosomal membrane integrity was determined by Neutral Red retention (NRR) test based on the lysosomes ability to concentrate the dye as it was described in El Haj et al. (2019). The tissue samples (30 mg) were incubated for $2 \mathrm{~h}$ with a saline solution containing NR, washed and fixed in formaldehyde $\left(0.5 \%\right.$ in $\left.1 \% \mathrm{CaCl}_{2}\right)$. After fixation, the formaldehyde impregnated tissue fragments were removed and frozen (up to one week). Dye was extracted in acid alcohol (1\% acetic acid in $50 \%$ ethyl alcohol) and analyzed spectrophotometrically at $550-\mathrm{nm}$.

The ability of exposures to induce cytochrome P450 (CYP450) activity was quantified as 7ethoxyresorufin O-deethylase (EROD) activity in the supernatant of $10 \% \mathrm{w} / \mathrm{v}$ homogenate by measuring the formation of resorufin at $572 \mathrm{~nm}$ (Klotz et al. 1984). The reaction was initiated by the addition of 0.5 mM NADPH. EROD activity was calculated using a molar extinction coefficient of $73.210^{3} \mathrm{M}^{-1} \cdot \mathrm{cm}^{-1}$ and referred to the soluble protein concentration.

Glutathione S-transferase (GST, EC 2.5.1.18) activity was assayed using GSH and 1-chloro-2,4dinitrobenzene (CDBN) as the substrate (Habig et al. 1974). The GST activity was expressed in $\mathrm{nmol}^{-1}$ ${ }^{1} \cdot \mathrm{mg}^{-1}$ soluble protein.

Caspase-3 (EC.3.4.22.56) activity as the marker of apoptosys was assayed colorimetrically in $25 \% \mathrm{w} / \mathrm{v}$ homogenate of digestive gland tissue based on the hydrolysis of peptide acetyl-Asp-Glu-Val-Asp pnitroanilide (Ac-DEVD-pNA) by caspase-3 that produces a colored product $p$-nitroaniline (pNA). The pNA was detected at $405 \mathrm{~nm}\left(\varepsilon_{\mathrm{mM}}=10.5 \mathrm{mM}^{-1} \cdot \mathrm{cm}^{-1}\right)$ (Du et al. 1997). The activity of caspase-3 was expressed in nmol pNA min ${ }^{-1} \mathrm{mg}^{-1}$ of soluble protein.

Citrate synthase (CS, EC 2.3.3.1) activity was measured in the $10 \% \mathrm{w} / \mathrm{v}$ homogenate of the digestive gland according to Flynn et al. (2015) as the maximum rate of increase in absorbance at $412 \mathrm{~nm}$, caused by the production of a coenzyme A-SH and monitored by DNTB. CS enzyme activity was calculated by subtracting the background activity (negative control) from the CS enzyme activity (positive reaction) for each sample and quantified using the molar extinction coefficient of DTNB $\left(14,150 \cdot \mathrm{M}^{-1} \mathrm{~cm}^{-1}\right)$.

\subsection{Zinc concentration in the tissue and metallothioneins}

The concentration of $Z n$ was measured in the digestive gland tissue ( $Z n-t)$ and the pooled MT-containing eluate (Zn-MT) received by chromatography utilizing the reaction of the complexation of $\mathrm{Zn}$ (II) with 2-(5bromo-2-pyridylazo)-5-[N-propyl-N-(3-sulfopropyl) amino]phenol disodium salt dihydrate (5-BrPAPS) (Wang et al. 2018). The samples were dried at $105^{\circ} \mathrm{C}$ for $24 \mathrm{~h}$ and then digested with $\mathrm{HNO}_{3}$. The received ash was dissolved in $1 \%$ trichloroacetic acid, then $0.6 \mathrm{M}$ 5-Br-PAPS in carbonate buffer $(\mathrm{pH} 8.9)$ 
was added. The mixture was incubated for $30 \mathrm{~min}$ at $20^{\circ} \mathrm{C}$. Zn concentration was evaluated from the absorbance of the metal-5-Br-PAPS complex at $560 \mathrm{~nm}$. Fe ions were masked with citric acid, and $\mathrm{Cu}$ ions were masked with salicylaldoxime, deferoxamine, and sodium citrate. The detection limit was $0.1 \mu \mathrm{g} \cdot \mathrm{g}^{-1}$ FW. Quality control was performed by the method of Standard Addition. Metal concentration in the tissue and MTs was expressed as nmol or $\mu \mathrm{g} \cdot \mathrm{g}^{-1} \mathrm{FW}$.

\subsection{Statistical analysis}

Results were expressed as mean \pm standard deviation. Metal in MTs analysis was repeated in four samples for each of two independent combined from five individuals replices in a group, resulting in $n=8$ for each group. For all other traits, the sample size was eight from eight individuals. Shapiro-Wilk test was used for the assessment of normality. Data were analyzed with parametric Student's t-test significant at $p<0.05$. Principal component analysis (PCA) was performed to assess the relations between measured parameters utilizing the rotation method Varimax. The adequacy of data was evaluated based on the value of the KMO and Bartlett's test of sphericity. Canonical discriminant analysis was utilised for the separation of the exposed groups. The IBM SPSS Statistics version 26 software for Windows was used for calculations. Correlation was significant at $p<0.05$ level $(r>0.304)$ and $p<0.01(r>0.393)$ (2-tailed), $\mathrm{n}=40$.

Integrated Biomarker Index (IBR) elaborated by Beliaeff and Burgeot (2002) was calculated for biomarkers (totally 14). The indices of CAP, EROD, GST, protein carbonyls (PC), GSH, GSSG, RI GSH, metallothionein concentration (MTSH), lysosomal integrity (NRR), caspase-3 activity (Cas-3), cholinesterase activity (ChE), citrate synthase (CS), Zn-metallothionein (Zn-MT) and Zn total (Zn-t) were used for the computation of data. The standardization of data was achieved by $\mathrm{Xi}$ calculation: $\mathrm{Xi}=(\mathrm{Mi}-$ $\mathrm{Mt}$ /SDi. For Ai calculation, the computation of data was made as to the Xe-Xc, assuming that the changes of the value in each exposed group $(\mathrm{Xe})$ in relation to control $(\mathrm{Xc})$ is corresponding to the stress or toxicity responses, and the value of standardized marker Xc was adjusted to zero. IBR value for each group was calculated as $[(A 1 \times A 2)+(A 2 \times A 3)+\ldots(A n \times \cdot A 1)] / 2$. Since the value of IBR is dependent on the number of markers, the termed IBR value was given as IBR/ $n$ with $n=14$.

\section{Results}

\subsection{Cellular soluble thiols and zinc accumulation in the digestive gland}

The level of GSH increased in all exposures except Rn, particularly, by 1.8 times, in the RnCpz-group. In the latter group, the level of GSSG was also increased. As a result, the RI GSH increased compared to control in all exposed groups except the Rn-group by 36.0-48.8\% (Fig. 1a-c). MT concentration increased by 33.6-57.7\% in all Rn-contained exposures, mostly in the RnT-group, whereas Cpz did not change the level of MT (Fig. 1d). Zn-t concentration decreased in the RnT- and Cpz-groups compared to control value by 15.5 and $24.3 \%$ correspondingly, whereas the level of Zn-MT increased in all groups, particularly by $\sim 53 \%$ in the RnT- and Cpz-groups (Fig. 1e and f). 


\subsection{Indexes of stress and toxicity}

The evaluation of oxidative stress responses indicated substantial activation of the TAC by $23.4-51.3 \%$ in all exposures (Fig. 2a). The level of protein oxidation products (PC) increased compared to control in all exposures except the Rn-group (Fig. 2b). The highest increase by $32.5 \%$ was recorded in RnT-group.

The monooxygenase-related biotransformation function (CYP450) attested from the EROD activity was greatly enhanced by 2.4-3 times in all treated groups except the Rn-group (Fig. 2c). The changes of GST activity compared to control occurred in single treatments, i.e., increase by $26.2 \%$ in the Rn-group and decrease by $21.9 \%$ in the Cpz-group. In contrast, no changes were evident in the joint treatments in the RnT- and RnCpz-groups (Fig. 2d).

For the indexes of toxicity, some differences were also found (Fig. 3). ChE activity increased compared to control value in the Rn-, RnCpz-and Cpz-groups and did not differ from control in the RnT-group (Fig. 3a). The lysosomal integrity decreased in the RnT-group, increased in the Cpz-group and did not change in the rest of the groups (Fig. 3b).

The activity of the central executive enzyme of apoptosis, caspase-3, was substantially increased in the molluscs' exposures to Rn and RnCpz (by 36.4\%) and was not changed in other treatment groups (Fig. 3c). The metabolic intensity was indicated by the citrate synthase activity. It enhanced compared to control in all exposures, except the Rn-group, particularly in the Cpz-related groups, by $36.5-43.0 \%$ (Fig. 3d).

\subsection{Data integration}

The Pearson correlation analysis revealed multiple associations among the studied indices in $U$. tumidus across all experimental groups (SI Tabl. B1). The greatest number of correlations was found for the indexes of oxidative stress and GSH. In opposite, MT and NRR did not show any correlations. The application of PCA to the datasets to identify relations between indices (Fig. 4a) shows a good distribution of the variables with a factor loading higher than $|0.37|$. The set of Zn-MT, TAC (ABTS*), PC, EROD, GSH, RI GSH and CS belonged positively to the first principal component (PC1) and Zn-t located opposite. The set of caspase-3, ChE and GST was related positively to PC2 and opposite to CS with factor loading higher than $|0.42|$. Generally, $53.6 \%$ of the variance was accounted for the first three factors.

According to Canonical discriminant analysis, all specimens in the C-, RnCpz- and Cpz-groups and 75\% of specimens in the Rn- and RnT-groups were classified correctly. Fig. $4 \mathrm{~b}$ shows that the $\mathrm{C}$ - and Rn-groups jointly (group centroids -7.55 and -3.96 , correspondingly) are well separated in the space of discriminant variables along the axis 1 compared to located oppositely the Cpz-group with the centroid value 7.33. Subjected to combined exposures, the RnT- and RnCpz-groups were placed between these opposite positions along axis 1 and located similarly with centroids values 2.97 and 2.51 along axis 2 .

The calculated values of IBR/ $\mathrm{n}$ in relation to baseline (control) value equaled $0.54,0.69,1.71$ and 1.84 , respectively for the $\mathrm{Rn}-\mathrm{RnT}-\mathrm{RnCpz}$ - and $\mathrm{Cpz}$-groups. The highest IBR/n values were observed in the 
RnCpz- and Cpz-group, indicating the particular increase in the A values for most indexes (Fig. 5). The input of Zn-MT was the highest similarly in all groups. The A values in the $\mathrm{Cpz}$ group were opposite to other groups for plural indexes. On the other hand, the changes compared to control in the Rn-group were lesser for all indices except Zn-MT and GSH.

\section{Discussion}

This study aimed to indicate whether the combine exposure or heating can distort the specific responses of bivalve molluscs to aquatic pollutants at lower possible environmental concentrations. Discriminant analysis indicated the lesser distinction from control for Rn-group, confirming the effect of concentration equalled 0.2 PNEC as almost negligible. The highest difference was detected for the Cpz-group (Fig. 4b, 5). Interestingly, the concerted exposures (RnT- and RnCpz-groups) produced similar integrative responses, distinct from each exposure to individual substance. However, a number of peculiar manifestations were indicated in each group.

4.1 Can Zinc-related parameters serve as specific biomarkers of effect for low concentrations of Roundup and chlorpromazine?

The involvement of $\mathrm{Zn}$ in cellular defence and regulation seems to be the common mechanism that can determine the resistance to adverse impacts. Various xenobiotics and physicochemical factors have been reported to result in the impairment of Zn metabolism, and subsequently, Zn deficiency in animals (Krężel and Maret 2016). As it has been shown for several organisms, Rn can chelate metals and cause their imbalance (Tsui et al. 2005; Liz Oliveira Cavalli et al. 2013; Mertens et al. 2018). Both Rn and Cpz can affect $\mathrm{Zn}$ functionality indirectly via Ca-depending processes whereas the cellular entry of $\mathrm{Zn}$ can be realized through several types of Ca-permeable channels (Bouron and Oberwinkler 2014; Hamaguchi et al. 2014). Particularly, Rn and glyphosate selective influence L-type Ca channels and their genes in the exposures of rat testis or isolated Sertoli cells and zebrafish embryos (Liz Oliveira Cavalli et al. 2013; Gaur and Bhargava 2019). Cpz also affects many Ca-dependent processes (Xu et al. 2010; Hamaguchi et al. 2014). Indeed, we found a decrease in the Zn uptake in the RnT- and Cpz-groups (Fig. 1a), whereas Rn per se did not change $\mathrm{Zn}$ t. Importantly, at twice higher concentration, than in this study, Rn also decreased the $\mathrm{Zn} \mathrm{t}$ level in the digestive gland of $U$. tumidus only in the mixture at elevated temperature (Khoma et al. 2021). Similarly, distortion of the response to Rn by warming was shown by Amid et al. (2018) in the tropical staghorn coral Acropora formosa. The specificity of the effect of $\mathrm{Cpz}$ on the molluscs is supported by the presence of a dopamine $D_{1}$-like receptor in the albumen gland of air-breathing freshwater snail Helisoma duryi (Planorbidae) (Mukai et al. 2004). Nevertheless, this effect of Cpz was abolished in the complex exposure of $U$. tumidus to Rn and Cpz. Thus, we confirm the ability of Rn and $\mathrm{Cpz}$ impact the $\mathrm{Zn}$ accumulation in the tissues, although for Rn only under the heating.

The elevated accumulation of $\mathrm{Zn}$ in MTs was the shared manifestation (Fig. 1f). MT plays a critical role in $\mathrm{Zn}$ homeostasis under various conditions but $\mathrm{Zn}$ chelating in the thiolate clusters of MT depends on the redox state of thiols (Krężel and Maret 2016). Adverse effects of different nature decrease the level of 
labile $\mathrm{Zn}$ and metalation of MT in molluscs even when the total level of this protein is increased (Khoma et al. 2021). In the present study, the elevation of Zn-MT was well coordinated with the TAC and GSH responses (Fig. 4a). Consequently, this common response can indicate the enhancing of antioxidant activity and redox state of thiols. In opposite, the loss of MT metalation is frequently accompanied by plural signs of toxicity. For example, in the exposure to $33.6 \mu \mathrm{g} / \mathrm{L}$ of Rn, the depletion of Zn-MT was accompanied by the decrease of the ChE and GST activities, lysosomal integrity, and increase in the GSSG level (Khoma et al. 2021). In the present study, the signs of toxicity were almost absent. This attested the low molecular weight thiols as the successful biochemical drivers that provide the redox power in the exposures of low-level toxicity and provide the hormetic-like response.

\subsection{Enzymes of biotransformation as the probable targets for Roundup and chlorpromazine}

Data concerning the biotransformation of $\mathrm{Rn}$ and $\mathrm{Cpz}$ by the enzymes of phases I and II are scant and contradictory. Phosphonate-based pesticide formulations are known to cause the reduction in CYP450 enzyme levels in mammals (Mesnage and Antoniou 2017). However, the exposure of rats to Rn in the drinking water caused a decrease of EROD activity in male, but an increase in the female specimens (Larsen et al. 2014). Concerning the $\mathrm{Cpz}$, it has been mentioned that a deficient number of studies were designed to investigate the environmental fate of any tricyclic antipsychotic drug (Trautwein and Kümmerer 2012). Cpz had to be classified as non-biodegradable in all of the biodegradation tests with aquatic bacteria (Trautwein and Kümmerer 2012; Jiménez et al. 2016). However, its biotransformation products have been elucidated by multiple-stage mass-spectrometry (Trautwein and Kümmerer, 2012). In the present study, the increase of EROD activity was not a specific for Cpz feature. The strong correlation between EROD and a set of indices of antioxidant and metabolic activities and Zn-MT attested this increase as a part of a well-coordinated, probably hermetic-like defensive response to low concentrations of xenobiotics (Fig. 4a).

The GST activity did not correlate with EROD in this and other studies on aquatic animals from polluted areas or exposed to several substances (Domingues et al. 2010). The decrease or absence of GST response has been reported in the exposures of molluscs to higher Rn or glyphosate concentrations (Matozzo et al. 2019; Khoma et al. 2021). In the present study, GST activation can be explained by the low-strength Rn impact. GST activation has been also indicated in the testes of rats exposed to Rn (Liz Oliveira Cavalli et al. 2013). For the Cpz, the decrease in GST activity was one of the most particular reactions observed in this study. The inhibition of GST has also been shown for the effect of Cpz in vitro (Türkan et al. 2020). Moreover, among four tested drugs, $\mathrm{Cpz}$ has been found to be the best inhibitor for the GST enzyme (Oliveira et al. 2015). Hence, the two manifestations confirmed in our study, Zn and GST levels' decrease, might be effect-specific for this drug. However, both of them were abolished in the combined RnCpz-exposure.

In the present study, the GST activity was coordinated with those of the ChE and caspase-3 (SI Tabl. B1, Fig. 4a). The responses of GST and ChE are frequently analysed jointly as the prospective biomarkers in molluscs (Domingues et al. 2010). For the organophosphates acute effect, the expected response is the 
depletion of ChE (Li et al. 2018; Matozzo et al. 2019), whereas the upregulation of ChE in molluscs is seldom detected and discussed (Domingues et al. 2010). In this study, upregulation of ChE can be a sign of the non-toxic level of exposure to $\mathrm{Rn}$, that is consistent with other manifestations in Rn-group. In the vertebrates, the simultaneous increase in ChE and caspase- 3 activities has been indicated (Hu et al. 2009), and ChE has been proposed as a marker for apoptosis (Zhang and Greenberg 2012). This common regularity has been detected for the neurons of insect Locusta migratoria, where the addition of the ChE inhibitors reduced apoptotic cell death (Knorr et al. 2020). In the freshwater mussels Unionidae, simultaneous increase of $\mathrm{ChE}$ and caspase-3 activities has been indicated under the effect of pesticides, pharmaceuticals and heating (Khoma et al. 2021). Nevertheless, the common regularity in alterations of GST, ChE and caspase-3 can not be explained unambiguously basing on the current study data. Hence, we found that EROD activation was a constituent of the common, probably hermetic-like, stress response, while the set of GST, ChE and caspase-3 activities was more exposure-specific.

\subsection{How can we attest the severity of injury?}

The analysis of each studied biomarker confirmed that we used low enough concentrations of xenobiotics, which did not provoke obvious toxicity. The mobilisation of antioxidants and alterations of metabolic activity correspond to low dose stimulation or hormetic response (Lefcort et al. 2008). This kind of response was evident from TAC and CS activation. A significant, but not a prominent increase of protein carbonylation can be regarded as the triggering signal for the antioxidant enhancement. Similarly, the EROD activation can induce antioxidants (He et al. 2017). Particularly, low-weight thiols seem to be of decisive importance. High inter-correlations were shown in the set of TAC (ABTS*), Zn-MT, GSH, RI GSH, CS and EROD (Fig. 4a).

GSH is on the first line of antioxidant defence as a radical scavenger. Plural examples show the involvement of GSH in the antioxidant activity in the bivalve molluscs (Regoli et al. 2011; Gnatyshyna et al. 2020; Khoma et al. 2021). In these examples and precisely under the exposures to Rn at different models, the responses of GSH\&GSSG are highly different (Larsen et al. 2014; Melo Tarouco et al. 2017) depending on the severity of impact. In any case, GSH and MTSH (last except Cpz-group) activation can support the redox balance and provide the Zn-chelating in the present study's model exposures.

In this study, the joint exposure to Rn and heating can be qualified as the most disturbing. Only in this group, the lysosomal integrity was decreased. Similar observation has been indicated previously at higher concentration of mixture included $\mathrm{Rn}$ and heating (Khoma et al. 2021). The loss of the lysosomal integrity is an approved sign of toxicity and thermal stress in molluscs (Negri et al. 2013; lzagirre et al. 2014; Koagouw and Ciocan 2018). However, the opposite effect on the lysosome integrity was indicated in the Cpz-group. This unusual effect has also been observed for the $\mathrm{Ca}$ channel blocker nifedipine (Khoma et al. 2021). Both these pharmaceuticals can be involved in the Ca-related functions of lysosomes, that explain the similarity of the lysosomal manifestattion. Indeed, it has been shown that the $\mathrm{pH}$ homeostasis in lysosomes/late endosomes is rather stable in the presence of cationic amphiphilic drugs and strictly maintained even after a longer treatment with Cpz (Hamaguchi et al. 2014). 
Generally, the calculated IBR-indices gave the possibility to analyze both specific and common traits of responses, and detect their severity (Fig. 5).

\section{Conclusions}

The applied low subchronic exposures to common aquatic pollutants allowed indicating hormetic-like mobilisation of antioxidant and metabolic responses in the bivalve molluscs with certain specificity in the Roundup- and chlorpromazine-exposed groups. Complex exposures abolished this specificity, and heating enhanced the toxicity of almost no-effect concentration of Roundup to molluscs. Discriminant analysis and IBR calculation of the battery of biomarkers highlighted the benefits of multi-marker expertise in identifying of response strength and specificity.

\section{Declarations}

\section{Ethical Approval and Consent to Participate}

All applicable international, national, and/or institutional guidelines for the care and use of animals were followed.

\section{Consent to Publish}

Not applicable.

\section{Authors Contributions}

Oksana Stoliar contributed to conception and design, acquisition, analysis, interpretation, drafted manuscript, and gave final approval. Levonas Manusadžianas contributed to conception, design, critically revised manuscript, and gave final approval. Lesya Gnatyshyna contributed to design, analysis and interpretation and gave final approval; Vira Khoma contibuted to experimental analysis, statistic preparation and gave final approval; Viktoria Martinyuk contibuted to sampling, analysis and gave final approval; Tetyana Matskiv contibuted to analysis, draft preparation and gave final approval; Vitaliy Baranovsky contributed to statistic preparation, acquisition and gave final approval, Mykola Gladiuk contibuted to sampling, draft preparation and gave final approval; Brigita Gylyte contributed to draft preparation and gave final approval.

\section{Funding}

This work has been granted by the Ministry of Education and Science of Ukraine to Oksana Stoliar (Project 132B and Ukrainian-Lithuanian R\&D Project No M19/2020) and by the Research Council of Lithuania (Project No S-LU-20-10 under the Lithuanian-Ukrainian Cooperation Program).

\section{Competing Interests}


The authors declare that they have no conflict of interest. Informed consent was obtained from all individual participants included in the study.

\section{Availability of data and materials}

The datasets generated and/or analysed during the current study (experimental data, calculation of IBR, and the applied methods) are available in the Mendeley Data repository by the following link http://dx.doi.org/10.17632/365bfpzs4w.3

\section{References}

1. Alkimin GD, Nunes B, Soares AMVM, Soares M, Bellot C, Gómez-Canela C, Barata C (2020) Daphnia magna responses to fish kairomone and chlorpromazine exposures. Chem Biol Interact 325:109123. https://doi.org/10.1016/j.cbi.2020.109123

2. Amid C, Olstedt M, Gunnarsson JS, Le Lan H, Tran Thi Minh H, Van den Brink PJ, Hellström M, Tedengren M (2018) Additive effects of the herbicide glyphosate and elevated temperature on the branched coral Acropora formosa in Nha Trang, Vietnam. Environ Sci Pollut Res 25:13360-13372. https://doi.org/10.1007/s11356-016-8320-7

3. Baresel C, Palm Cousins A, Hörsing M, Ek M, Ejhed H, Allard AS, Magnér J, Westling K, Wahlberg C, Fortkamp U, Söhr S (2015) Pharmaceutical residues and other emerging substances in the effluent of sewage treatment plants. IVL Swedish Environmental Research Institute, Report B, 2226.

4. Bonansea RI, Filippi I, Wunderlin DA, Marino DJ, Amé MV (2018) The fate of glyphosate and AMPA in a freshwater endorheic basin: an ecotoxicological risk assessment. Toxics 6(1):3.

https://doi.org/10.3390/toxics6010003

5. Bouron A, Oberwinkler J (2013) Contribution of calcium-conducting channels to the transport of zinc ions. Pflugers Arch 466:381-387. https://doi.org/10.1007/s00424-013-1295-z

6. Du Y, Bales KR, Dodel RC, Hamilton-Byrd E, Horn JW, Czilli DL, Simmons LK, Ni B, Paul SM (1997) Activation of a caspase 3-related cysteine protease is required for glutamate-mediated apoptosis of cultured cerebellar granule neurons. Proc Natl Acad Sci USA 94:11657-11662.

7. Domingues I, Agra AR, Monaghan K, Soares AM, Nogueira AJ (2010) Cholinesterase and glutathioneS-transferase activities in freshwater invertebrates as biomarkers to assess pesticide contamination. Environ Toxicol Chem 29(21):5-18. https://doi.org/10.1002/etc.23

8. El Haj Y, Bohn S, Souza MM (2019) Tolerance of native and invasive bivalves under herbicide and metal contamination: an ex vivo approach. Environ Sci Pollut Res Int 26(30):31198-31206. https://doi.org/10.1007/s11356-019-06256-x

9. Ellman GL, Courtney KD, Andres VJ, Featherstone RM (1961) A new and rapid colorimetric determination of acetylcholinesterase activity. Biochem Pharmacol 7:88-90. https://doi.org/10.1016/0006-2952(61)90145-9 
10. Flynn EE, Bjelde BE, Miller NA, Todgham AE (2015) Ocean acidification exerts negative effects during warming conditions in a developing Antarctic fish. Conserv Physiol 3(1):cov033. https://doi.org/10.1093/conphys/cov033

11. Frédéric $O$, Yves $P$ (2014) Pharmaceuticals in hospital wastewater: their ecotoxicity and contribution to the environmental hazard of the effluent. Chemosphere 115:31-39. https://doi.org/10.1016/j.chemosphere.2014.01.016

12. Gaur H, Bhargava A (2019) Glyphosate induces toxicity and modulates calcium and NO signaling in zebrafish embryos. Biochem Biophys Res Commun 513(4):1070-1075. https://doi.org/10.1016/j.bbrc.2019.04.074

13. Giménez V, Nunes B (2019) Effects of commonly used therapeutic drugs, paracetamol, and acetylsalicylic acid, on key physiological traits of the sea snail Gibbula umbilicalis. Environ Sci Pollut Res 26:21858-21870. https://doi.org/10.1007/s11356-019-04653-w

14. Gnatyshyna L, Khoma V, Mishchuk O, Martinyuk V, Sprinǵe G, Stoliar O (2020) Multi-marker study of the responses of the Unio tumidus from the areas of small and micro hydropower plants at the Dniester River Basin, Ukraine. Environ Sci Pollut Res 27:11038-11049. https://doi.org/10.1007/s11356-020-07698-4

15. Griffith OW (1980) Determination of glutathione and glutathione disulfide using glutathione reductase and 2-vinylpyridine. Anal Biochem 106(1):207-212. https://doi.org/10.1016/00032697(80)90139-6

16. Habig WH, Pabst MJ, Jakoby WB (1974) Glutathione S-transferases. The first enzymatic step in mercapturic acid formation. J Biol Chem 249(22):7130-7139.

17. Hamaguchi R, Haginaka J, Tanimoto T, Kuroda Y (2014) Maintenance of luminal pH and protease activity in lysosomes/late endosomes by vacuolar ATPase in chlorpromazine-treated RAW264 cells accumulating phospholipids. Cell Biol Toxicol 30:67-77. https://doi.org/10.1007/s10565-014-92692

18. He L, HeT, Farrar S, Ji L, Liu T, Ma X (2017) Antioxidants maintain cellular redox homeostasis by elimination of reactive oxygen species. Cell Physiol Biochem 44(2):532-553. https://doi.org/10.1159/000485089

19. Hu T, Fu Q, Liu X, Zhang H, Dong M (2009) Increased acetylcholinesterase and caspase-3 expression in the brain and peripheral immune system of focal cerebral ischemic rats. J Neuroimmunol 211(12):84-91. https://doi.org/10.1016/j.jneuroim.2009.04.002

20. Izagirre U, Errasti A, Bilbao E, Múgica M, Marigómez I (2014) Combined effects of thermal stress and $\mathrm{Cd}$ on lysosomal biomarkers and transcription of genes encoding lysosomal enzymes and HSP70 in mussels, Mytilus galloprovincialis. Aquat Toxicol 149:145-156.

https://doi.org/10.1016/j.aquatox.2014.01.013

21. Jiménez JJ, Muñoz BE, Sánchez MI, Pardo R, Vega MS (2016) Fate of the drug chlorpromazine in river water according to laboratory assays. Identification and evolution over time of degradation 
products. Sorption to sediment. Chemosphere 162:285-292.

https://doi.org/10.1016/j.chemosphere.2016.07.107

22. Khoma V, Gnatyshyna L, Martinyuk V, Mackiv T, Mishchenko L, Manusadžianas L, Stoliar O (2021) Common and particular biochemical responses of Unio tumidus to herbicide, pharmaceuticals and their combined exposure with heating. Ecotoxicol Environ Saf 208:111695. https://doi.org/10.1016/j.ecoenv.2020.111695

23. Khoma VV, Gnatyshyna LL, Martinyuk VV, Mackiv TR, Mishchuk NY, Stoliar O (2020) Metallothioneins contribution to the response of bivalve mollusk to xenobiotics. Ukr Biochem J 92(5):87-96. https://doi.org/10.15407/ubj92.05.087

24. Klotz AV, Stegeman JJ, Walsh C (1984) An alternative 7-ethoxyresorufin O-deethylase activity assay: a continuous visible spectrophotometric method for measurement of cytochrome P-450 monooxygenase activity. Anal Biochem 140(1):138-145. https://doi.org/10.1016/00032697(84)90144-1

25. Knorr DY, Georges NS, Pauls S, Heinrich R (2020) Acetylcholinesterase promotes apoptosis in insect neurons. Apoptosis 25:730-746. https://doi.org/10.1007/s10495-020-01630-4

26. Koagouw W, Ciocan C (2018) Impact of metformin and increased temperature on blue mussels Mytilus edulis - evidence for synergism. J Shellfish Res 37(3):467-474. https://doi.org/10.2983/035.037.0301

27. Krężel A, Maret W (2016) The biological inorganic chemistry of zinc ions. Arch Biochem Biophys 611:3-19. https://doi.org/10.1016/j.abb.2016.04.010

28. Larsen K, Najle R, Lifschitz A, Maté ML, Lanusse C, Virkel GL (2014) Effects of sublethal exposure to a glyphosate-based herbicide formulation on metabolic activities of different xenobioticmetabolizing enzymes in rats. Int J Toxicol 33(4):307-318. https://doi.org/10.1177/1091581814540481

29. Lefcort H, Freedman Z, House S et al (2008) Hormetic effects of heavy metals in aquatic snails: is a little bit of pollution good? EcoHealth 5(1):10. https://doi.org/10.1007/s10393-008-0158-0

30. Li P, Snyder GL, Vanover KE (2016) Dopamine targeting drugs for the treatment of schizophrenia: past, present and future. Curr Top Med Chem 16(29):3385-3403. https://doi.org/10.2174/1568026616666160608084834

31. Liz Oliveira Cavalli VL, Cattani D, Rieg CEH, Pierozan P, Zanatta L, Benedetti Parisotto E, Filho WD, Silva FRMB, Pessoa-Pureur R, Zamoner A (2013) Roundup disrupts male reproductive functions by triggering calcium-mediated cell death in rat testis and Sertoli cells. Free Radic Biol Med 65:335-346. https://doi.org/10.1016/j.freeradbiomed.2013.06.043

32. Louis F, Rocher B, Barjhoux I, Bultelle F, Dedourge-Geffard O, Gaillet V, Bonnard I, Delahaut L, PainDevin S, Geffard A, Paris-Palacios S, David E (2020) Seasonal monitoring of cellular energy metabolism in a sentinel species, Dreissena polymorpha (bivalve): effect of global change? Sci Total Environ 725:138450. https://doi.org/10.1016/j.scitotenv.2020.138450 
33. Lowry OH, Rosebroungh HJ, Farr AL, Randall RJ (1951) Protein measurement with folin phenol reagent. J Biol Chem 193:265-275. https://doi.org/10.1016/S0021-9258(19)52451-6

34. Martin OV, Adams J, Beasley A et al (2019) Improving environmental risk assessments of chemicals: steps towards evidence-based ecotoxicology. Environ Int 128:210-217. https://doi.org/10.1016/j.envint.2019.04.053

35. Matozzo V, Fabrello J, Marin MG (2020) The effects of glyphosate and its commercial formulations to marine invertebrates: a review. J Mar Sci Eng 8(6):399. https://doi.org/10.3390/jmse8060399

36. Matozzo V, Munari M, Masiero L, Finos L, Marin MG (2019) Ecotoxicological hazard of a mixture of glyphosate and aminomethylphosphonic acid to the mussel Mytilus galloprovincialis (Lamarck 1819). Sci Rep 9:14302. https://doi.org/10.1038/s41598-019-50607-0

37. Maycock D, Crane M, Atkinson C, Johnson J (2012) Proposed EQS for Water Framework Directive Annex VIII Substances: Glyphosate (For consultation). Water Framework Directive - United Kingdom Technical Advisory Group (WFD-UKTAG). Sniffer, Edinburgh, 121 pp.

https://www.wfduk.org/sites/default/files/Media/Glyphosate\%20-\%20UKTAG.pdf. Accessed February 2021.

38. Melo Tarouco F, De Godoi FGA, Velasques RR, Da Silveira Guerreiro A, Geihs MA, Da Rosa CE (2017) Effects of the herbicide Roundup on the polychaeta Laeonereis acuta: cholinesterases and oxidative stress. Ecotoxicol Environ Saf 135:259-266._https://doi.org/10.1016/j.ecoenv.2016.10.014

39. Mertens M, Höss S, Neumann G, Afzal J, Reichenbecher W (2018) Glyphosate, a chelating agent relevant for ecological risk assessment? Environ Sci Pollut Res 25:5298-5317. https://doi.org/10.1007/s11356-017-1080-1

40. Mesnage R, Antoniou MN (2017) Facts and Fallacies in the Debate on Glyphosate Toxicity. Front Public Health 5:316-323. https://doi.org/10.3389/fpubh.2017.00316

41. Miller TH, Ng KT, Bury ST, Bury SE, Bury NR, Barron LP (2019) Biomonitoring of pesticides, pharmaceuticals and illicit drugs in a freshwater invertebrate to estimate toxic or effect pressure. Environ Int 129:595-606. https://doi.org/10.1016/j.envint.2019.04.038

42. Mukai ST, Kiehn L, Saleuddin ASM (2004) Dopamine stimulates snail albumen gland glycoprotein secretion through the activation of a D1-like receptor. J Exp Biol 207(14):2507-2518. https://doi.org/10.1242/jeb.01052

43. Negri A, Oliveri C, Sforzini S, Mignione F, Viarengo A, Banni M (2013) Transcriptional response of the mussel Mytilus galloprovincialis (Lam.) following exposure to heat stress and copper. PLoS One 8(6):e66802. https://doi.org/10.1371/journal.pone.0066802

44. Nelson M, Adams T, Ojo C, Carroll MA, Catapane EJ (2018) Manganese toxicity is targeting an early step in the dopamine signal transduction pathway that controls lateral cilia activity in the bivalve mollusc Crassostrea virginica. Comp Biochem Physiol C Toxicol Pharmacol 213:1-6. https://doi.org/10.1016/j.cbpc.2018.07.002

45. Oliveira LLD, Antunes SC, Gonçalves F, Rocha O, Nunes B (2015) Evaluation of ecotoxicological effects of drugs on Daphnia magna using different enzymatic biomarkers. Ecotoxicol Environ Saf 
119:123-131. https://doi.org/10.1016/j.ecoenv.2015.04.028

46. Patra RW, Chapman JC, Lim RP, Gehrke PC, Sunderam RM (2015) Interactions between water temperature and contaminant toxicity to freshwater fish. Environ Toxicol Chem. 34:1809-1817. https://doi.org/10.1002/etc.2990

47. Payton SL, Johnson PD, Jenny MJ (2016) Comparative physiological, biochemical and molecular thermal stress response profiles for two unionid freshwater mussel species. J Exp Biol 219:35623574. https://doi.org/10.1242/jeb.140129

48. Plaze M, Attali D, Petit AC, Blatzer M, Simon-Loriere E, Vinckier F, Cachia A, Chrétien F, Gaillard R (2020) Repurposing chlorpromazine to treat COVID-19: the reCoVery study. L'Encéphale 46(3):169172. https://doi.org/10.1016/j.encep.2020.05.006

49. Re R, Pellegrini N, Proteggente A, Pannala A, Yang M, Rice-Evans C (1999) Antioxidant activity applying an improved ABTS radical cation decolorization assay. Free Radic Biol Med 26(9-10):12311237. https://doi.org/10.1016/S0891-5849(98)00315-3

50. Regoli F, Benedetti M, Giuliani ME (2011) Antioxidant defenses and acquisition of tolerance to chemical stress. In: Amiard-Triquet C, Rainbow PS, Romeo M (ed) Tolerance to Environmental Contaminants. CRC Press, Boca Raton, FL, pp 153-173. https://doi.org/10.1201/b10519-9

51. Reznick AZ, Packer L (1994) Oxidative damage to proteins: spectrophotometric method for carbonyl assay. Meth Enzymol 233:357-363. https://doi.org/10.1016/s0076-6879(94)33041-7

52. Roesijadi G, Fowler B (1991) Purification of invertebrate metallothioneins. Meth Enzymol 205B:263273. https://doi.org/10.1016/0076-6879(91)05106-6

53. Stip E, Rizvi TA, Mustafa F, Javaid S, Aburuz S, Ahmed NN, Abdel Aziz K, Arnone D, Subbarayan A, Al Mugaddam F, Khan G (2020) The Large Action of Chlorpromazine: Translational and Transdisciplinary Considerations in the Face of COVID-19. Front Pharmacol 11:577678. https://doi.org/10.3389/fphar.2020.577678

54. Trautwein C, Kümmerer K (2012) Degradation of the tricyclic antipsychotic drug chlorpromazine under environmental conditions, identification of its main aquatic biotic and abiotic transformation products by LC-MSn and their effects on environmental bacteria. J Chromatogr B 889-890:24-38. https://doi.org/10.1016/j.jchromb.2012.01.022

55. Tsui MTK, Wang WX, Chu LM (2005) Influence of glyphosate and its formulation (Roundup®) on the toxicity and bioavailability of metals to Ceriodaphnia dubia. Environ Pollut 138:59-68. https://doi.org/10.1016/j.envpol.2005.02.018

56. Türkan F, Calimli MH, Kanberoğlu GS, Karaman M (2020) Inhibition effects of isoproterenol, chlorpromazine, carbamazepine, tamoxifen drugs on glutathione S-transferase, cholinesterases enzymes and molecular docking studies. J Biomol Struct Dyn 39(9):3277-3284. https://doi.org/10.1080/07391102.2020.1763200

57. Viarengo A, Ponzano E, Dondero F, Fabbri R (1997) A simple spectrophotometric method for metallothionein evaluation in marine organisms: an application to Mediterranean and Antarctic molluscs. Mar Environ Res 44(1):69-84. https://doi.org/10.1016/S0141-1136(96)00103-1 
58. Wang J, Niu Y, Zhang C, Chen Y (2018) A micro-plate colorimetric assay for rapid determination of trace zinc in animal feed, pet food and drinking water by ion masking nd statistical partitioning correction. Food Chem 245:337-345. https://doi.org/10.1016/j.foodchem.2017.10.054

59. Xu B, Xu ZF, Deng Y, Yang JH (2010) Protective effects of chlorpromazine and verapamil against cadmium-induced kidney damage in vivo. Exp Toxicol Pathol 62(1):27-34. https://doi.org/10.1016/j.etp.2008.12.009

60. Yang JL, Li YF, Bao WY, Satuito CG, Kitamura H (2011) Larval metamorphosis of the mussel Mytilus galloprovincialis Lamarck, 1819 in response to neurotransmitter blockers and tetraethylammonium. Biofouling 27(2):193-199. https://doi.org/10.1080/08927014.2011.553717

61. Zhang X-J, Greenberg DS (2012) Acetylcholinesterase involvement in apoptosis. Front Mol Neurosci 5:40. https://doi.org/10.3389/fnmol.2012.00040

\section{Figures}


$\square \mathrm{C} \square \mathrm{Rn} \square \mathrm{RnT} \square \mathrm{RnCpz} \square \mathrm{Cpz}$
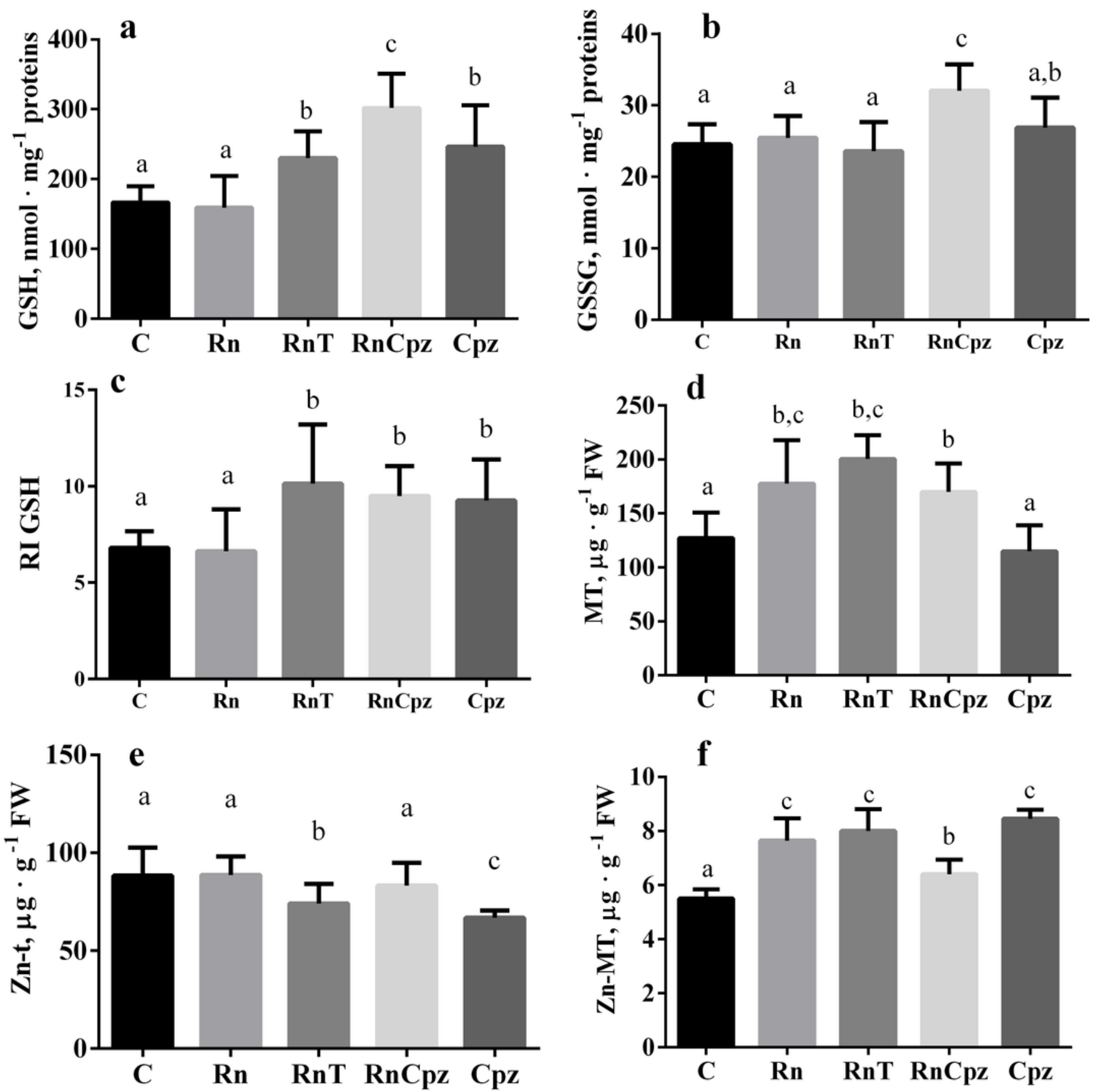

Figure 1

Concentrations of soluble thiols and $\mathrm{Zn}$ in the digestive gland of $\mathrm{U}$. tumidus exposed to Roundup (Rn), Roundup and heating (RnT), Roundup and chlorpromazine (RnCpz), and chlorpromazine ( $\mathrm{Cpz}$ ) during 14 days. (a) GSH. (b) GSSG. (c) Redox index of glutathione (RI GSH). (d) Metallothionein (MT). (E) Zn in the tissue $(\mathrm{Zn}-\mathrm{t})$. ( $\mathrm{F}) \mathrm{Zn}$ in metallothioneins $(\mathrm{Zn} M T)$. Data are presented as means \pm standard deviations $(\mathrm{n}=$ 8). Different letters above the columns indicate significantly different values $(P<0.05)$ 

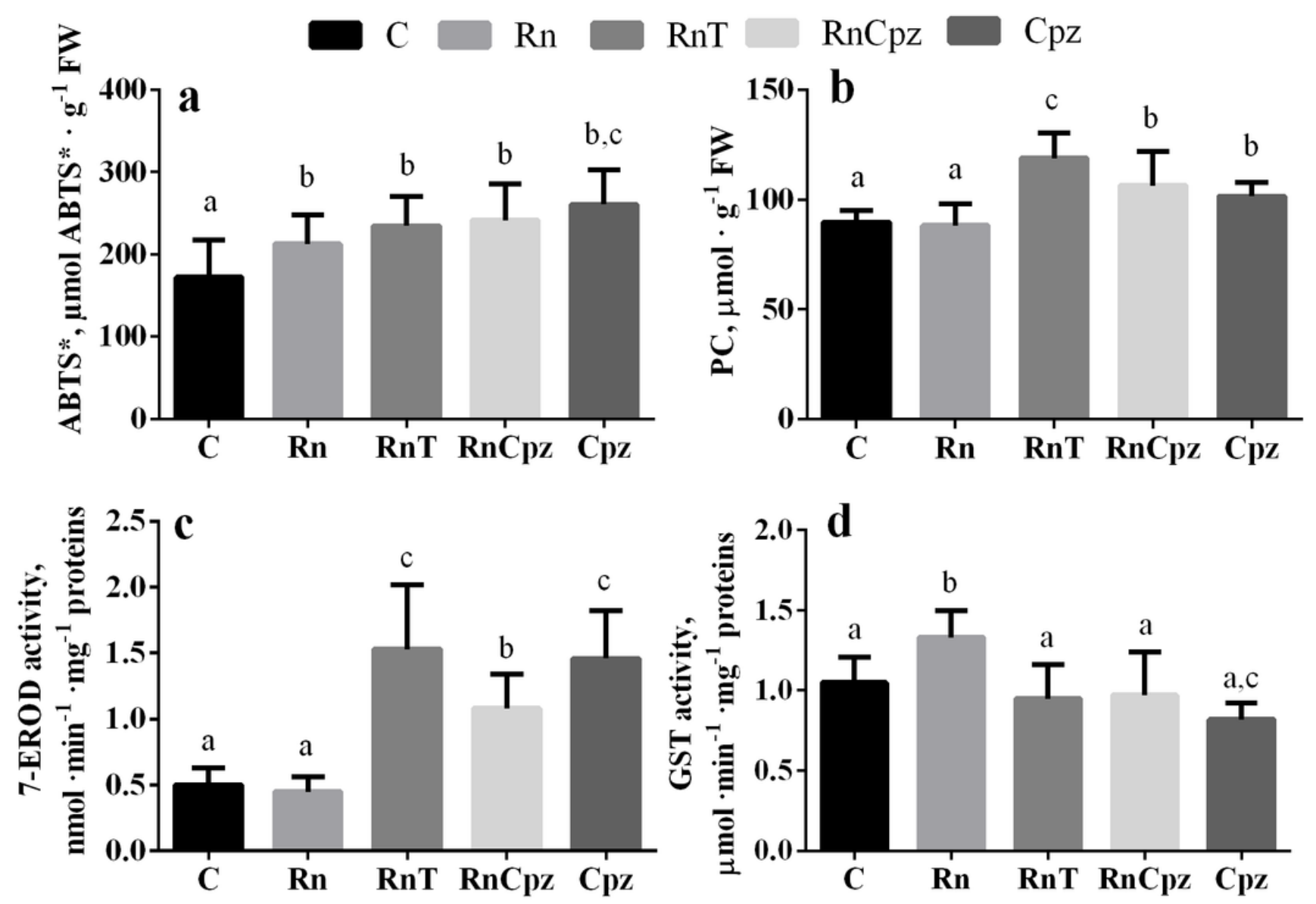

Figure 2

Oxidative stress and biotransformation parameters in the digestive gland of $\mathrm{U}$. tumidus after 14 days of experimental exposures to Roundup (Rn), Roundup and heating (RnT), Roundup and chlorpromazine (RnCpz) and chlorpromazine (Cpz) during 14 days. (a) Total antioxidant (ABTS radical scavenging) activity (ABTS*). (b) Protein carbonyls production (PC). (c) 7-EROD activity; (d) GST activity. Data are presented as means \pm standard deviations $(n=8)$. Different letters above the columns indicate significantly different values $(P<0.05)$ 
$\square \mathrm{C} \square \mathrm{Rn} \square \mathrm{RnT} \square \mathrm{RnCpz} \square \mathrm{Cpz}$
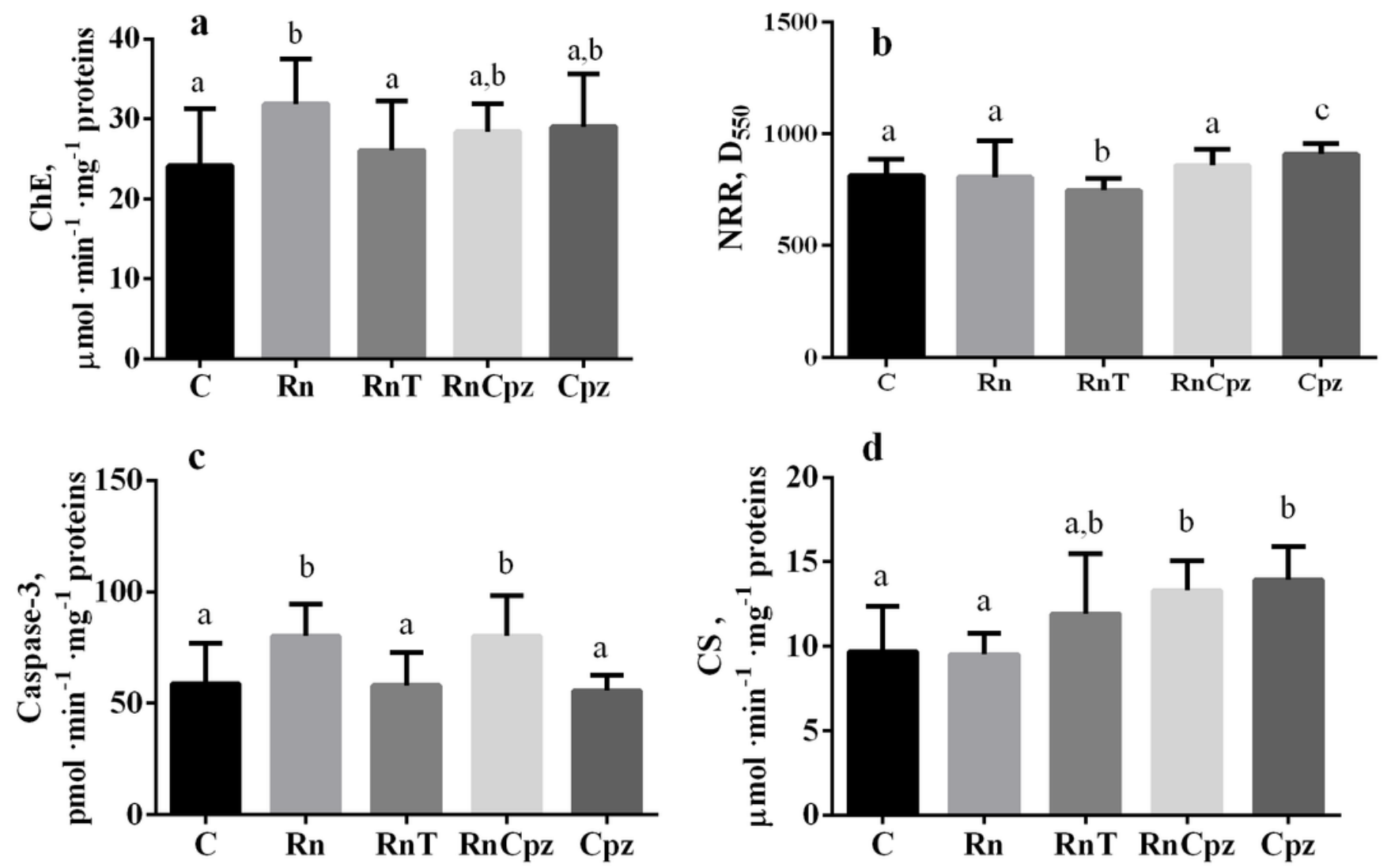

Figure 3

Cytotoxicity and metabolism parameters in the digestive gland of U. tumidus exposed to Roundup (Rn), Roundup and heating (RnT), Roundup and chlorpromazine (RnCpz) and chlorpromazine ( $\mathrm{Cpz}$ ) during 14 days. (a) Cholinesterase (ChE) activity. (b) Lysosomal membrane stability (NRR). (c) Caspase-3 activity. (d) Citrate synthase (CS) activity. Data are presented as means \pm standard deviations $(n=8)$. Different letters above the columns indicate significantly different values $(P<0.05)$ 

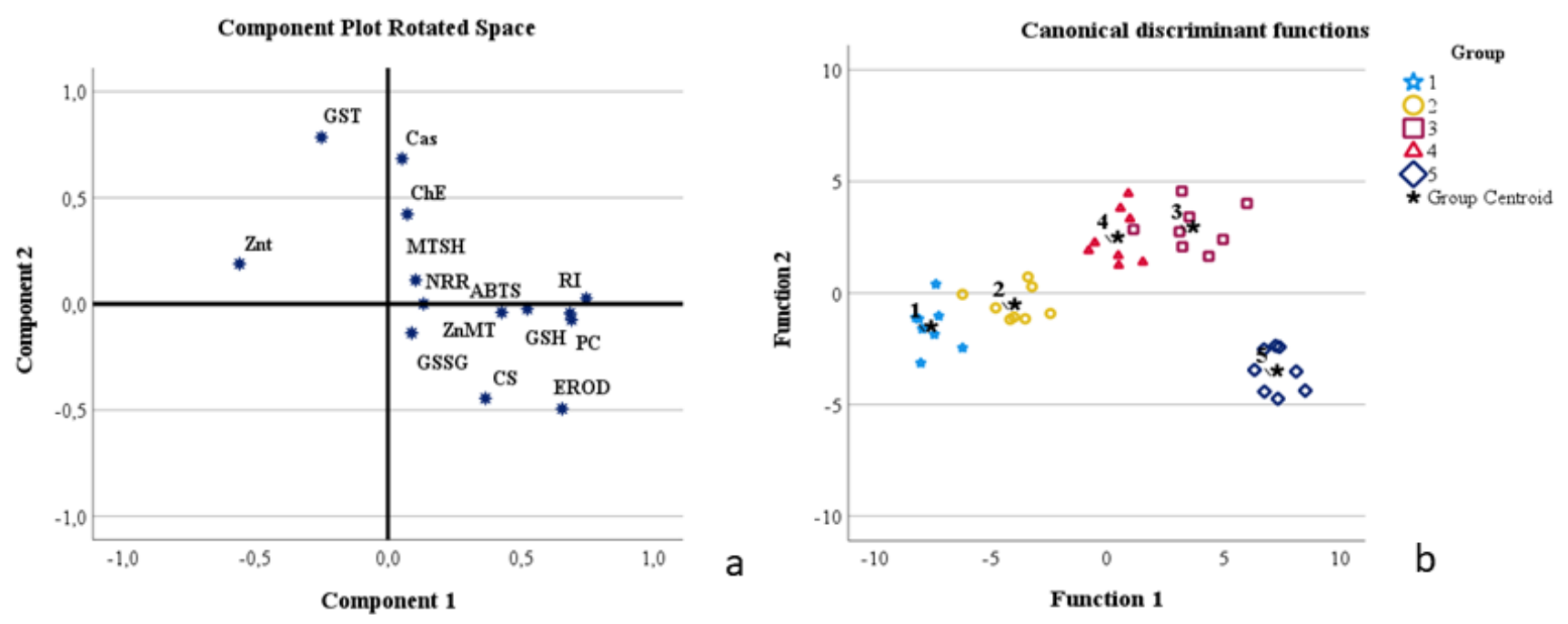

\section{Figure 4}

The results of Principal Component Analysis applied to reveal the relations between measured parameters (a) and scatter plots of the canonical values on the first and second canonical discriminant axes to discriminate the groups of molluscs (b). a: The abbreviations see in the text. B: control group (1); groups exposed to Roundup (2), Roundup and heating (3), Roundup and chlorpromazine (4), and chlorpromazine (5) during 14 days 


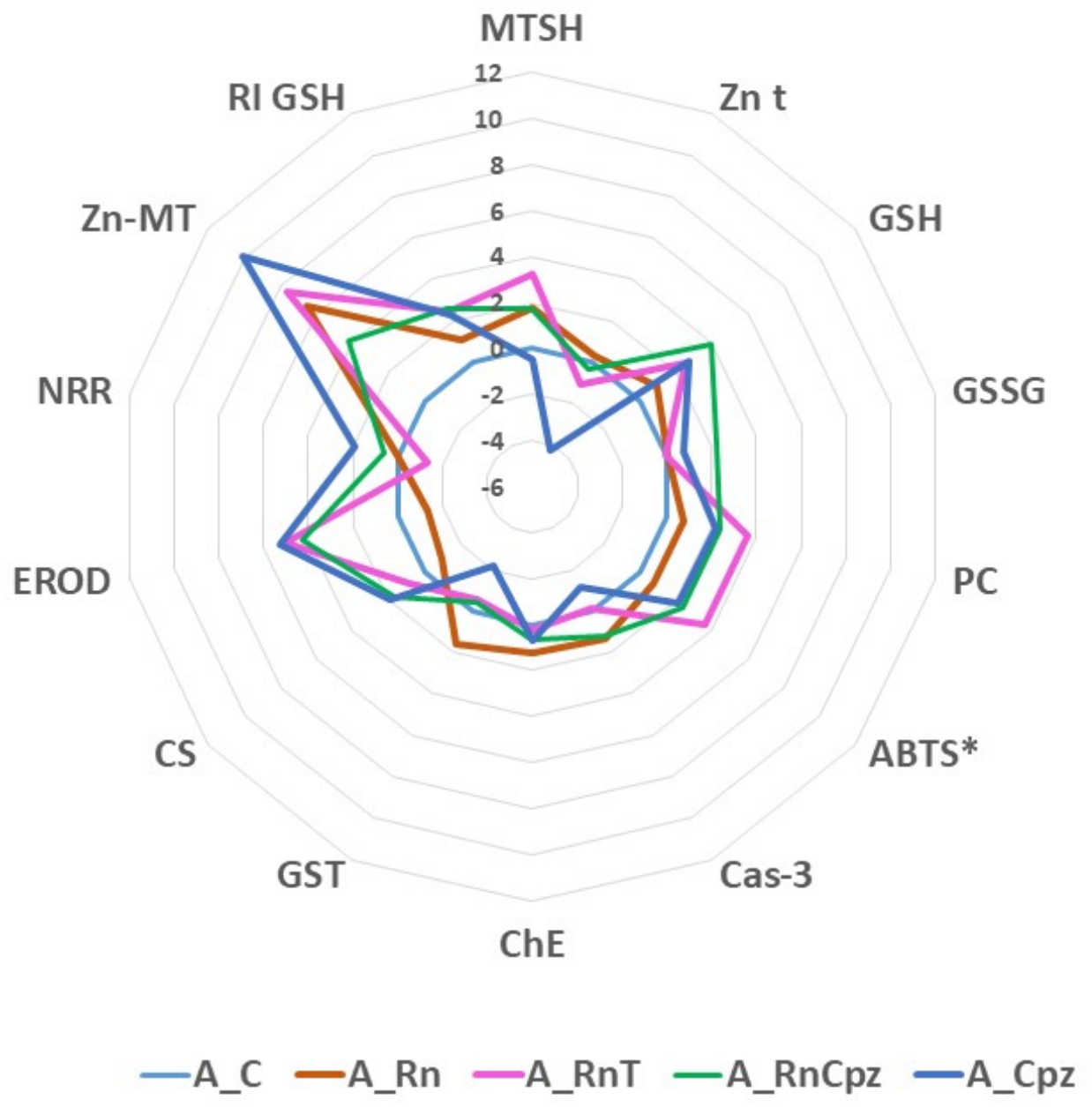

Figure 5

Biomarker star plots (Ai variables) of multiple biomarker responses of U. tumidus exposed to Roundup $(\mathrm{Rn})$, Roundup and heating (RnT), Roundup and chlorpromazine (RnCpz), and chlorpromazine (Cpz) during 14 days compared to control values considered as zero values (C)

\section{Supplementary Files}

This is a list of supplementary files associated with this preprint. Click to download.

- Graphicalabstract.tif

- SupplementalfilesKhomaetal1.docx 